\title{
Why Are We Inside?
}

Uere is the basic truth: behind the myth of equality before the law stands 1 the entrenched relations of power and privilege as embodied in the racist, classist, patriarchal state and its corporate benefactors (Wacquant, 2010). It is this, the inequality before the law and the attendant substantial bias that exists in its content and in its reinforcement, not our upbringing or a lack of community values, that explains why prison is deemed an acceptable and even an automatic response for one set of individuals and not for another. It is this that truly explains why we prisoners are inside. $O f$ course poverty and a shitty upbringing contribute largely to 'street crime', and of course we prisoners need all the help and healing that we can get. However, until there is a fundamental change in the way that society is structured to oppress, control, and discriminate against the very scapegoats that it helped to create in the first place - the economically marginalized, racialized people, the alienated, people living with substance use issues, the psychologically bruised and battered, the "unfit" or "damaged" mothers and daughters - the likelihood of having a criminal label and of being locked up in a 'correctional' system that not only fails to correct, but which actively makes it extremely difficult for any meaningful change to occur, will continue to increase as one's social status decreases. So too will criminalization remain associated with poverty or a lack of community values and will continue to be disconnected from the greed, exploitation, and power of the corporate state and its cronies.

I work tirelessly towards positive change. Many prisoners, in fact, manage to improve their lives through hard work and, crucially, with the love, support, and kindness of others. But here is the thing: this improvement comes not because of, but despite being incarcerated. Indeed, considering the cold, impersonal, dehumanizing concentration camps that prisons are, 'rehabilitation' cannot be anything, but a continuous uphill struggle for even the most determined and well-intentioned of prisoners. Consider the following syllogism, a form of reasoning in which a conclusion is drawn from two premises. The major premise is that people housed in vile and violent places are very likely to become vile and violent themselves. The minor premise is that prisoners are housed in prisons, which are vile and violent places. The conclusion is that prisoners are very likely to become vile and violent. Simple, eh? Well, it truly is that simple! Since most prisoners are eventually released back into society, it should be equally 
simple to all Canadians of all political stripes that incarceration, offered as a solution to social harm, ultimately serves only to create more harm and violence. Now, I am not suggesting that we immediately stop incarcerating people and close down all prisons. That would not be realistic. I do believe, however, that this is the direction in which we should be moving and that this process can begin now.

Right now, most prisoners and would-be prisoners can be better served through alternatives to incarceration that includes imaginative combinations of community service, health and social supports, counselling, restorative justice processes, and so forth. Right now, we can stop the abomination of punishing and caging those living with mental illness (with which prisons are replete) and we can funnel - or re-funnel - resources into mental health care vast sums of it from the billions of dollars we literally give to continue to criminalize and cage human beings. And, right now we can get down to the crucially important work of analyzing and changing the conditions that lead to violence and harm in the first place, and that make scapegoats of entire communities. Here is where transformative justice processes can play a pivotal role (see Morris, 2000).

Transformative justice can be understood as a vision for communitybased forms of justice which respond to harm and conflict not by punishment and incarceration, but by encouraging support, healing, and understanding (ibid). This process includes the victim, the accused, and the community. Transformative justice goes beyond specific relations and conflicts, and looks to the empowerment of people to challenge the very structures of oppression that lie at the root of violence and social harm, and which create and sanction scapegoating.

Transformative justice, then, directly implicates communities as a whole in fostering harm and conflict, and, as a solution to such, calls for nothing less than the transformation of our world so as to make it a safer and more just place for all people, regardless of class, race, creed, gender identity, sexual orientation, ability or disability (Kim, 2018). However, we must act prudently. We must erode the power of the state to violently intervene in our lives in proportion to the degree that we develop the community power to make us independent of the state and its false solutions to social problems. This restructuring process requires that we look beyond the old reformabolition dichotomy and critically examine reforms uniquely in terms of their 
amenability to corruption by oppressive elites, and that we instead advance reformist methods strategically towards the long-term revolutionary goals of abolition and social transformation. Each little reform, each little victory, makes us stronger, bolder, more demanding and less willing to compromise on matters essential to freedom, equality, and justice for all. Before we know it, the walls of power are pushed far back enough to allow for a new social order to spread and to eventually supplant the old.

The development of this new social order requires our challenging and finding remedies to structures of oppression (patriarchy, capitalism, racism, ableism, militarism, heterosexism) that foster social harm and violence. The question, "Why are we inside?", can perhaps be reframed as "Why do prisons exist?" It is clear, I hope, that the answer has nothing to do with public safety or reducing crime. As good an answer as any is provided by the researcher and social activist Angela Davis (2005), who, in her book Abolition Democracy: Prisons, Democracy, and Empire, writes that prisons are used as "a way of disappearing people in the false hope of disappearing the underlying social problems they represent" (2005, p. 41). In other words, it truly is all about scapegoating.

Relatedly, we need more building of community ties, community trust and community support systems. We need to multiply centres of community life and press for a reshaping of the social order along decentralized lines so that more nonviolent and anti-oppressive actions can initiate the revitalization of our communities (Kim, 2018). We also need to do more work to break old patterns of domination and create new patterns of mutual exchange and democratic decision-making; on transmuting old energies based on hate, indifference, and prejudice into new energies based on a real sense of community; and on cultivating human resources like love, trust, compassion, acceptance, forgiveness, confidence, imagination, leadership, responsibility, understanding, self-control, self-reliance, and kindness. All this work and so much more besides it is required if we hope to create a more just, humane, and genuinely democratic social order. But it is a process and it requires prudence. Dialogues about bogus policies, practices, and categories supporting prisons and the myth that they have some radical potential to shift collective ideas about punishment and incarceration allows us to mobilize support towards the kind of structural transformation that may one day render unnecessary the question "Why are we inside?" So speak! 


\section{REFERENCES}

Davis, Angela Y. (2005) Abolition Democracy: Beyond Empire, Prisons, and Torture, New York: Seven Stories Press.

Kim, Mimi (2018) "From Carceral Feminism to Transformative Justice: Women-ofcolor Feminism and Alternatives to Incarceration", Journal of Ethnic and Cultural Diversity in Social Work, 27(3): 219-233.

Morris, Ruth (2000) Stories of Transformative Justice, Toronto: Canadian Scholars Press.

Wacquant, Loïc (2010) "Class, Race, and Hyperincarceration in Revanchist America", Daedalus, 139(3): 74-90.

\section{ABOUT THE AUTHOR}

Anonymous Prisoner 1 is a voracious reader and aspiring agent of positive change with over 20 years inside and an ear increasingly attuned to the "still, sad music of humanity" (Wordworth). From straight-A student but painfully shy and insecure child, to prisoner, to repeat prisoner, to "untreatable" prisoner, the author - out of sheer exhaustion and despair - has recently turned to meditation and Buddhism for help. 